\title{
Eric Carlsson
}

\section{Ett förändrat vårdlandskap \\ Debatten om e-hälsa i svensk medicinsk fackpress}

\begin{abstract}
A transformed landscape of care - The debate on e-health in Swedish specialist press This article examines the debate on e-health in the Swedish medicine specialist press. E-health is not an entirely new phenomenon, yet digital care such as video meetings and chat via apps with medical personnel has increased rapidly in Sweden during the last few years, and the government's goal is to provide the "world's best e-health" by the year 2025. Implementation of digital technology in public health care has transformed the ways in which the Swedish health system works, including what it means to be a patient and a provider of care. These transformations of care have led to an intense debate in the specialist press. The aim of this article is to examine how e-health as a concept is attributed different meanings in the Swedish medical professional press and to analyse the conflict lines that shape this formation of meaning. The method used is discourse analysis of articles published in two journals: Dagens Medicin and Läkartidningen. The study identifies three organizing metaphors in which meaning is established: e-health as competition, e-health as economy, and marketization of e-health as an ethical problem. These organizing metaphors were all connected to possibilities and problems in the digital health care system such as more flexible and accessible care, increased costs, aggressive marketing from private e-health providers, and conflicts of interest among health providers. The analysis shows how these organizing metaphors construct not only meanings of e-health but also what it means to be a patient and a caregiver in the current public health care system in Sweden.
\end{abstract}

Eric Carlsson, docent och lektor i medie- och kommunikationsvetenskap, institutionen för kultur- och medievetenskaper, Umeå universitet.

Kontakt: eric.carlsson@umu.se 


\section{Inledning}

Det har skett stora förändringar i den svenska vården de senaste åren när det gäller digitalisering. Många har nog sett de nya privata vårdföretagens reklamkampanjer där de vill sälja in vård via svenskarnas datorer och smartmobiler. Företaget KRY, som 2014 etablerades som ett "startupföretag", har snabbt vuxit till att bli en av de största privata aktörerna inom e-hälsa i Sverige. Enligt KRY:s årsberättelse för 2018 ökade antalet vårdmöten under 2017 med 740 procent jämfört med året innan. Coronaepidemin sägs även ha bidragit till ett "genombrott för Kry" som nästan "dubblat sin volym" under de första månaderna av 2020 (Leijonhufvud 2020). Min Doktor som ägs av ICA Gruppen, ett bolag verksamt inom bland annat dagligvaruhandeln och apoteksbranschen är en annan ledande aktör tillsammans med företag som exempelvis doktor.se, Doktor 24 och Medicoo. Affärsidén för den typen av verksamheter går ut på att patienter med relativt enkla åkommor ska betala en patientavgift på några hundralappar för att konsultera en läkare digitalt via videolänk eller chatt. Vissa bolag tar inte ut någon patientavgift alls. Landstingen i Sverige debiteras sedan mångdubbelt patientens kostnad som en del i vårdföretagens vinstmål. Kritiker har varnat för att den här typen av digital vård leder till stora kostnader för samhället där skattemedel går till de enklare former av sjukvård som företagen erbjuder, i stället för till primärvården, som anses vara underfinansierad. Mellan åren 20192020 beräknas kostnaderna för privata vårdappar dubbleras och överstiga en miljard kronor (SVT 2020). Problemet sägs även vara att företagens digitala vård inte är behovsstyrd i tillräcklig utsträckning. I många fall kräver de åkommor som konsulteras inte ett läkarbesök överhuvudtaget, menar kritikerna (Andersson, Sjögreen \& Åsberg 2017). Företagen själva, och en del ansvariga politiker, hävdar i stället att införandet av e-hälsa kommer att spara närmare hundra miljarder i skattemedel årligen på grund av effektivitetsvinster (Kangero \& Persson 2017; Forslund \& Röstin 2017). Det här sättet att tala om vård som en ekonomisk och etisk fråga är visserligen ingenting nytt men i takt med e-hälsans framväxt under det senaste decenniet har digitaliserad vård i Sverige blivit allt mer omdiskuterad.

Syftet med artikeln är att undersöka hur e-hälsa som begrepp tillskrivs mening i svensk medicinsk fackpress samt analysera de konfliktlinjer som präglar denna betydelsebildning. Det görs genom att synliggöra de organiserade metaforer som kommer till uttryck i debatten om införandet av ny digital vårdteknologi. Följande frågor ställs: Hur gestaltas e-hälsa i fackpressen, det vill säga vilka betydelser tillskrivs digitala tekniker och vårdpraktiker? Hur representeras vårdpersonal, patienter och andra centrala aktörer? Vilka konfliktytor förekommer, vilka problem respektive möjligheter knyts till e-hälsa som ny vårdpraktik? 


\section{Tidigare forskning}

Den snabba teknologiska utvecklingen inom digital vård och en ständig lansering av nya digitala verktyg och applikationer inom vårdsektorn gör att det är svårt att se e-hälsobaserade vårdpraktiker som någonting entydigt. E-hälsa bör i stort betraktas som ett paraplybegrepp för en mängd olika former av vårdtekniker där digital kommunikation kan anses vara en central aspekt (Melander Wikman, Jansson \& BergvallKåreborn 2012). Även begrepp som "telemedicin", "online-vård", "digital vård", "digital hälsa" och "virtuell vård" innefattas i definitionen av e-hälsa som här används.

Mycket av den internationella forskning som har gjorts om e-hälsa är av utvärderande karaktär och belyser frågor om hur digitala lösningar i vården enklast ska kunna implementeras och hur effektiva de är (Ekeland, Bowes \& Flottorp 2010). I en forskningsöversikt (Kruse et al. 2016) listas de hinder som forskare identifierat när det gäller implementering av e-hälsorelaterad vård på en mer global nivå. De vanligaste svårigheterna enligt deras kartläggning handlar om ekonomi, digital kompetens och teknologiska problem, men även motvilja till förändring hos både patienter och personal samt frågor om patientintegritet och patientsäkerhet (Kruse et al. 2016).

Mindre vanligt är studier som undersöker politiska och sociala aspekter av digitaliseringen av vården, vilket den här studien är ett försök till. Deborah Lupton (2014) gör en översikt av internationell hälsoforskning som går bortom de utvärderande perspektiven genom att sätta in e-hälsa i vad som kan beskrivas som en sociopolitisk kontext. E-hälsa har exempelvis beforskats som ett uttryck för den så kallade self-tracking-rörelsen, som handlar bland annat om att ansvaret för vården i högre utsträckning än tidigare läggs på individen och att vården införlivas i en kommersiell kontext (Sharon 2016; Lupton 2017). I fokus står den uppsjö av mobila teknologier som bara det senaste decenniet har lanserats för att människor ska kunna mäta och räkna sin egen hälsa genom olika kroppsnära verktyg. Dessa verktyg ses ofta som någonting emancipatoriskt för både personal och patienter, bland annat eftersom teknologin sägs hjälpa individer att få kontroll över sin hälsa på ett mer transparent sätt (Melander Wikman et al. 2012). Forskare har även intresserat sig för hur digitala vårdpraktiker skapar stora dataflöden som möjliggör en ny typ av övervakning och hantering av medicinska data som inte var möjlig före digitaliseringen och spridningen av mobila enheter, som exempelvis smartmobiler, och lyfter fram risker och förtjänster med sådana system (Lupton 2018).

I en policystudie om digitalisering och äldrevård diskuteras hur virtuella hälsorum för äldre patienter i glesbygd är starkt sammankopplade till diskurser om såväl teknikoptimism som delaktighet $i$ vården och hur det kan försvåra att vara äldre vårdtagare på andra sätt (Lindberg \& Carlsson 2018). Det finns även forskning som ligger utanför digitaliseringen av vården som i sammanhanget är relevant. Studier av vårdpolicy visar hur en nyliberal logik som bland annat innebär ökad privatisering och stora för- 
hoppningar på kostnadseffektivisering genom konkurrens präglar organiseringen av vården (Andersson \& Kvist 2015; Lindberg \& Lundgren 2018). I detta systemskifte, som i Sverige har pågått sedan början av 1990-talet, har valfrihet setts som ett ledord och marknadifiering av vård och omsorg har skrivits fram som någonting som ska stärka individen genom att de själva fritt kan välja vårdgivare (Andersson \& Kvist 2015; Dahlgren 2018). Det speglas även i lagstiftning, bland annat i form av lagen om valfrihetssystem (LOV) (2008), som trädde i kraft 2009. Ett av de problem som lyfts fram i forskningen är att vårdtagare inte alltid har möjlighet att välja på grund av exempelvis ålder och hälsa och att det problemet inte beaktas i offentlig och politisk policy om vård, vilket kan leda till ökad ojämlikhet i vården. Även Dahlgren (2008) betonar, i en studie av vården i Stockholmsregionen, problem med ökad ojämlikhet i vård som privatiseras och styrs av vinstintressen snarare än vårdbehov. Dahlgren (2018) menar att vårdvalssystem i Sverige har öppnat upp för de offentligt finansierade digitala vårdföretagen att växa "explosionsartat" (Dahlgren 2018 s. 58).

Som denna översikt visar har forskning om e-hälsa ofta varit av utvärderande karaktär medan färre studier har undersökt digitaliseringen av vården som en meningsskapande praktik. I likhet med de policystudier av svensk vårds organisering som exemplifieras ovan, och i enlighet med ett diskursteoretiskt perspektiv, fokuserar den här studien på den betydelsebildning av e-hälsovård som manifesteras i delar av den ledande svenska medicinska fackpressen.

\section{Material, teori och metod}

Materialet som undersöks består huvudsakligen av artiklar ur de två ledande svenska tidskrifterna inom medicinsk fackpress. Dessa är Dagens Medicin (239) och Läkartidningen (83). Läkartidningen ägs av Läkarförbundet som svarar för ledarsidorna. Övrigt material är obundet. Dagens Medicin ägs av Bonnier Business Media AB. Tidskriften är oberoende och bevakar sjukvårdsbranschen. Följande sökord har använts i databasen mediearkivet retriever.se där tidskrifterna finns representerade: "digital vård", "onlinevård", "virtuell vård", "ehälsa", "e-hälsa" samt "telemedicin". Totalt har 328 artiklar ur de två tidskrifterna undersökts. Artiklarna är publicerade mellan åren 2010 och 2019 (januari). Tidsspannet motiveras av att den politiska styrningen av det svenska vårdsystemet förändrades under den tidsperioden med en ökad användning av digital vård. Därutöver har enstaka artiklar från bland annat Dagens Nyheter och Dagens Industri samt från vissa av vårdföretagens webbsidor inkluderats för att bättre kunna kontextualisera den debatt som förts i fackpressen. Materialet som helhet kan ses som relativt varierat och består av olika typer av texter (nyhetstexter, debattartiklar och i viss mån företagstexter) som tillsammans representerar olika inslag i diskursen om e-hälsa. 
Fokus för den här studien är att genom diskursanalys undersöka hur e-hälsa som begrepp tillskrivs mening i svensk medicinsk fackpress samt synliggöra de konfliktlinjer som formar denna betydelsebildning. Debatten om e-hälsa kan ses som en del av ett styrsystem som tillskriver e-hälsa betydelser. Sådan betydelsetillskrivning sker ofta men inte alltid horisontellt mellan olika publika och privata aktörer (i det här fallet fackförbund, intresseförbund, läkare, konsulter, politiker, vårdföretag och journalister). I studien är det emellertid inte aktörerna i sig som är i fokus utan de system av mening (diskurser) som de förhåller sig till och som texterna ingår i. Diskursbegreppet definieras utifrån en poststrukturalistisk syn där det betraktas som ett betydelsebärande strukturellt system av likhet och åtskillnad (Torfing 2005).

All data har noggrant analyserats och kodats med hjälp av mjukvara för kvalitativ dataanalys. Återkommande och besläktade koder har sedan slagits samman och presenteras i analysen som övergripande "organiserade metaforer" (Hansen \& Sørensen 2005 s. 96). De benämns e-hälsa som tävling, e-hälsa och ekonomi och marknadifiering av e-hälsa som ett etiskt problem. Begreppet organiserade metaforer används som ett analytiskt verktyg för att ringa in den betydelsetillskrivning som sker i materialet. Organiserade metaforer har likheter med diskursteorins begrepp flytande signifikanter (Laclau \& Mouffe 1985), som innebär att olika tecken i en diskurs konkurrerar om att slå fast betydelser av diverse sociala fenomen. Användandet av e-hälsa kan exempelvis i vissa sammanhang relateras till teknikutveckling och framstegstankar, medan i andra fall e-hälsa kan länkas till oönskade vinstuttag från skattemedel av privata vårdföretag. Diskursen om e-hälsa är således långt ifrån entydig och kan därför ses som ett relativt öppet fält där hegemoni inte råder.

En fråga som ställs i artikeln är hur e-hälsa artikuleras, det vill säga hur vissa tecken knyts till begreppet och andra inte i form av organiserade metaforer som bidrar till att forma betydelser om digitala lösningar inom vården. Inom vilka områden skapas någorlunda enhetliga betydelser av hur digital vård bör praktiseras och var uppstår konfliktytor? Det finns, som Žižek skriver, "ett ideologiskt utrymme" (Žižek 1989 s. 95) för konflikt när det inte råder konsensus kring vad någonting representerar, i det här fallet den nya digitala vårdens betydelser.

Studien ställer även frågor om hur gestaltningarna av e-hälsa förhåller sig till andra diskurser av ekonomisk, social och politisk art. En ingång i analysen är exempelvis att resonera kring hur digitala teknologier kan ses som styrmedel för en accelererande förändring av vårdsektorn som innefattar nya sätt att bedriva och organisera vård på. En inspiration är Hartmut Rosas (2013) makroteori om det "accelererande samhället". Rosa menar att kommunikationsteknologier tillsammans med rådande ekonomiska system utgör viktiga delar som förväntas skynda på accelerationen för social 
förändring och krympa avstånden i livsvärlden i stort, till exempel hur e-hälsa tenderar att göra vård och omsorg till en fråga om konkurrens och patienter till konsumenter som ska köpa vård på en marknad, oberoende av var de befinner sig. Det betyder emellertid inte att vårdteknologier är neutrala utan att dess betydelser skapas bland annat genom hur teknologin tillskrivs mening medialt.

\section{Resultat: E-hälsa i fackpressen}

I materialet har tre sammanlänkade organiserade metaforer identifierats: $e$-hälsa som tävling, e-hälsa och ekonomi samt marknadifiering av e-hälsa som ett etiskt problem. Dessa utgör återkommande sätt att gestalta problem och möjligheter med e-hälsa i vården. De ger en bild av hur de sociala och teknologiska förändringar som införandet av e-hälsa bär med sig manifesteras i medial diskurs och hur digital teknologi förväntas få effekter på olika vårdpraktiker och på professionens arbete.

\section{E-hälsa som tävling}

En av de mer framträdande organiserade metaforerna i materialet har en form och ett innehåll där e-hälsa tillskrivs betydelser med hjälp av tävlingsmetaforer. I artiklarna blir de nya digitala vårdformerna någonting som kan vinnas, erövras, konkurreras med, hinnas ikapp, eller tvärtom göra att svensk vård hamnar efter. Citatet nedan kommenterar den svenska regeringens pressmeddelande om en framtida vision att bli "bäst på e-hälsa":
År 2025 ska Sverige vara världsledande på att tillvarata digitaliseringens möjligheter inom hälso- och sjukvården för att främja jämlik hälsa, delaktighet och ta tillvara på enskildas resurser. Enkelt uttryckt ska Sverige vara världsbäst på e-hälsa. (Läkartidningen 2016-03-23)

När e-hälsa gestaltas som tävling är patienter inte särskilt framträdande och inte heller vårdpersonal. Snarare ligger fokus på en mer abstrakt nivå där globala aktörer föreställs kämpa mot varandra. E-hälsa som diskursivt tecken länkas till föreställningar om nationer, landsting eller vårdföretag, men också chefer och konsulter, som antas vilja konkurrera med teknikutveckling och implementering av nya innovationer inom den framväxande digitala vården. Tävlingsmetaforen är återkommande i flera av artiklarna men utgör inte bara ett återkommande sätt att representera e-hälsa på utan det förekommer också faktiska tävlingar i e-hälsa. Så skriver Dagens Medicin: "Nu är det upp till bevis för alla som tror på möjligheterna med e-hälsa. Nominera ert bidrag till IT i vårdenpriset. I november utser vi dem som är bäst i grenen" (2014-04-09). 
I en del av artiklarna gestaltas även e-hälsa på ett sätt där det varnas för risken att inte ha hunnit så långt i tävlingen. I en text lyfts exempelvis chefer inom vården fram som en viktig del för att nationen inte ska "hamna på efterkälken": "Har de verksamhetsnära cheferna inte mandat att prioritera utvecklingsarbete kommer Sverige ohjälpligt att hamna på efterkälken när det gäller innovation och nytänkande" (Läkartidningen 2016-03-23). Om inte cheferna tillåts agera genom att införa ny digital teknologi förväntas man alltså hamna efter andra. En vanlig röst i materialet är konsultens. Här intervjuas en amerikansk expert på e-hälsa om den svenska regeringens målsättning att bli bäst i världen:

- Jag tycker helt klart att det är ett ambitiöst men möjligt mål. Det kommer inte att bli lätt, säger Robert Wah och skrattar. - Men inget som är värt insatsen är lätt, eller hur? Det är en ambitiös plan, men det är bra att ha en plan och en strategi. Det är så man rör sig framåt. (Läkartidningen 2017-05-03).

I citatet konstrueras en bild av den digitala vården där den ses som ett slags spel där det går att vinna eller förlora någonting, och det är underförstått att man ska vilja få tillbaka "insatsen". Planer och strategier framstår som viktiga för idéen om ett ständigt framåtskridande, att nå målet - det blir en förutsättning för att kunna röra sig framåt. Att artikeln citerar en expert kan antas stärka nödvändigheten i denna logik. Liknande tankegångar uttrycks i Dagens Medicin i en debattartikel med titeln Alla måste fråga sig: Kan detta göras bättre med modern teknik? Artikeln är skriven av en tidigare moderat landstingspolitiker och numera rådgivare till företag inom e-hälsa:

\begin{abstract}
Svensk välfärd halkar efter med att ta till sig digitalisering och ny teknik. Ett land värt att studera är Estland, som dragit nytta av modern teknik för att skapa välfärd i klass med den svenska. Varför har vi i Sverige med våra förutsättningar inte kommit lika långt? (Dagens Medicin 2017-11-08)
\end{abstract}

Som exemplet visar framstår Sverige som om landet var på väg att förlora någonting eftersom vården sägs halka efter. Estland som nation däremot föreställs ha kommit längre i rörelsen framåt genom att de redan har anammat modern teknik. Teknologin framträder som en självklar lösning för att kunna komma långt. I dessa exempel tecknas alltså en bild av teknikens utveckling som central för e-hälsa som blir avhängig de olika ländernas kamp mellan varandra. I den organiserade metaforen om e-hälsa som ett tävlingslopp framställs den befintliga vården som om den går "långsamt", men genom införandet av e-hälsa kan vårdens utveckling nu börja "röra på sig ordentligt": 


\section{Socialvetenskaplig tidskrift 2020:2}

Det är svårt med förändring och lätt att göra sig lustig över hur långsamt den i själva verket kan krypa fram över landstingens linoleummattor. Men nu börjar saker och ting faktiskt röra på sig ordentligt. De stora nationella e-hälsoprojekten som gemensam läkemedelslista och personligt hälsokonto är visserligen inte i mål, men gott och väl på upploppet. Vissa mindre regionala och lokala projekt har i princip redan klippt målsnöret även om tyngre löpare som 3R/2R knappt lämnat startblocken och passerat första kurvan. [...] Ett vunnet lopp, lite vila och sedan nya utmaningar. Längre sträckor. (Dagens Medicin 2016-04-13)

I texten, där tävlingsmetaforen är tydlig, framställs aktörerna som "löpare" där vissa redan "klippt målsnöret" medan andra just lämnat "startblocken". Det gamla systemets tröghet symboliseras med att vårdens förändring vanligtvis kryper "fram över landstingens linoleummattor". Samtidigt gestaltas e-hälsoarbetet som om fler tävlingar behöver vinnas.

I andra exempel blir den digitala tekniken mer indirekt länkad till tävlingsmetaforen genom föreställningarna om utveckling. Svensk sjukvård beskrivs som om den inte hängde med i teknikutveckling och var föråldrad, ja, till och med primitiv:

Svensk sjukvård är måhända känd för att vara tekniskt avancerad, men den respons jag fick när jag ur rockfickan halade upp den ena urmodiga manicken efter den andra, gav mig känsla av att vi kanske befinner oss i stenåldern. [...] Jag frågade konsulten om det kanske går att lösa sådant här i framtiden. Han sa kort: "Tekniken finns och används sen länge. Mycket länge. Överallt". Dock inte i detta hörn av svensk sjukvård. (Läkartidningen 2011-08-10)

Konsulten får här företräda det moderna, målet dit svensk sjukvård för tillfället ska nå, medan den befintliga vården föreställs ligga årtusenden efter i teknisk utveckling på grund av "urmodiga manicker". "Kanske befinner [vi] oss i stenåldern", undrar skribenten som i texten tituleras biträdande överläkare. Att vården behöver förändras genom mer allomfattande teknikanvändning och modernare teknologi förefaller därmed nödvändigt. På det sättet blir en modernistisk logik en del av tävlingsmetaforen genom vilken e-hälsa begripliggörs. I några av artiklarna uttrycks emellertid mer tveksamhet till själva idén om e-hälsa som en tävling, här från Läkartidningens medicinska redaktör:

Tänker vi verkligen rätt kring e-hälsa? När regeringen glatt proklamerade sin vision att Sverige år 2025 ska vara världsbäst på att använda digitaliseringens och e-hälsans möjligheter var jag till en början entusiastisk. Äntligen? [...] Men vid närmare eftertanke är jag mer skeptisk. [...] Hur mäter man egentligen e-hälsa? (Läkartidningen 2018-03-14) 
Ett liknande resonemang förs i Dagens Medicin där själva tävlingsmetaforen beskrivs som meningslös eftersom det lyfts fram att det inte går att mäta e-hälsoteknologi på ett meningsfullt sätt: "Jag vet inte vilket land som i dag leder VM, men det gör ingen annan heller. Det går nämligen inte att mäta på något meningsfullt sätt" (Dagens Medicin 2016-02-22).

Hur kan vi förstå talet om e-hälsa som en tävling där vården förväntas nå längre, där olika vårdaktörer ska konkurrera och inte släpa efter, där man ska "pensionera" gammal teknik? Kanske kan den organiserade metaforen om e-hälsa som en tävling kopplas till en redan etablerad och närvarande diskurs i samhället om digitalisering som tenderar att avpolitisera teknologin? Drömmar om att införa mer och snabbare teknologi inom vården kan ses som ett uttryck för de accelerationsstrategier som Rosa (2013) menar länge har format moderna samhällen både teknologiskt, socialt och ekonomiskt. Enligt en teknologisk accelerationsprincip är målet alltid att byta ut befintlig teknologi med nyare former som ska vara ännu effektivare, kunna nå ut till fler på ett snabbare och mer direkt sätt. Följer inte tävlingsmetaforen just en sådan princip? En kontinuerlig utveckling av vården genom digital teknik tycks bli ett mål $i$ sig att uppnå medan det framstår som mer oklart varför och till vad teknologin egentligen ska användas, mer än att konkurrera med andra nationer och landsting.

\section{E-hälsa och ekonomi}

Artiklarna i fackpressen tar i många fall avstamp i den omorganisering av vård som skett i Sverige de senaste åren i och med etableringen av nya privata vårdaktörer. I den delen av debatten organiserar ekonomiska metaforer betydelsetillskrivningen av e-hälsa. Att vård och ekonomi är tätt sammanlänkade visar även tidigare forskning om e-hälsa (Kruse et. al. 2018). Som en bakomliggande kontext kan nämnas att omorganiseringen av vård i Sverige har inneburit att riskkapitalbolag har satsat stora belopp på nya vårdföretag. E-hälsoföretaget KRY har som exempel mottagit närmare en miljard svenska kronor från riskkapitalbolag som Creandum, Project A och Index Ventures. År 2017 tog de in tvåhundra miljoner och i januari 2018 ytterligare drygt en halv miljard enligt uppgifter i Dagens Industri (Karlsson 2018). KRY bedriver vårdverksamhet i Sverige, Norge, Spanien, Frankrike och Storbritannien och är därigenom störst i Europa inom digital vård. Nu har de expanderat ytterligare genom att rikta in sig på den nya, snabbt växande marknaden "mental ohälsa" som antas ge mycket goda intäkter (Ström 2017). I april 2019 förvärvade KRY den "empatiska chattboten" Enjo som ska hjälpa människor med sin mentala hälsa (Bengtsson 2019). Även företaget Min Doktor, som ägs av ICA Gruppen, har "fyllt på kassan rejält" och mottagit hundratals miljoner kronor av bland annat riskkapitalbolaget EQT Ventures (Leijonhufvud 2017; Wisterberg 2016). ICA Gruppen äger samtidigt Sveriges största privata apotekskedja, Apotek Hjärtat, med 390 butiker utspridda i landet. En av kon- 
kurrenterna, den "finske vårdjätten" Oriola, satsade 2018 hundra miljoner kronor på företaget doktor.se. Oriola äger också 325 svenska apotek som går under namnet Kronans Apotek (Törnwall 2018). Ytterligare 100 miljoner till doktor.se togs in 2019 i en "kapitalrunda" av Bonnier Ventures. Doktor.se kommer även under 2019 att lansera en app för djurvård och de har "stora förhoppningar att detta ska öka deras intäkter rejält" eftersom det, enligt dem själva, finns 102 miljoner katter och 84 miljoner hundar som potentiella patienter i Europa (Heijbel \& Tullberg 2019). Samtidigt som dessa nya digitala vårdbolag värderas högt på finansmarknaden, och därigenom kan tillförskaffa sig investeringsmedel, finansieras delar av deras verksamhet av skattemedel, vilket i materialet både artikuleras som en möjlighet och som ett ekonomiskt problem för vården i samhället i stort. Länken mellan e-hälsa och ekonomi kan sägas utgöra en betydande konfliktyta i det undersökta materialet.

I texterna återfinns ett ambivalent förhållningssätt till att införa digitala vårdteknologier med avseende på de ekonomiska följder som sägs uppstå med bland annat kommersiella aktörer inom den digitala vårdsektorn. Till viss del gestaltas förhållandet mellan digital vård och ekonomi som någonting som skapar nya möjligheter. I en artikel i Dagens Medicin uttrycker sig skribenten på följande vis:

- Det är jättebra att man kopplar ihop affärer och medicin. Ett skäl att vi inte har kommit längre inom e- hälsa är kanske att många inte är vana att göra det, säger Nina Sellberg, professor i e-hälsa och forsknings- och innovationsansvarig vid 1177 Vårdguiden. (Dagens Medicin 2015-04-15)

Nyckeln till att kunna "komma längre" inom medicinen sägs vara att göra vård till en affärsverksamhet och att det tidigare har funnits en ovana att göra så. "Det är jättebra", säger den intervjuade som också tillskrivs rollen som expert i egenskap av hennes befattningar som professor och forsknings-och innovationsansvarig vid 1177 Vårdguiden. Sammanlänkningen mellan "affärer och medicin" framstår därmed som både viktig och rimlig för att utveckla digital vård på ett mer generellt plan. En annan av möjligheterna som lyfts fram är att införandet av digitaliserad vård kommer att leda till ekonomiska besparingar i form av tidsvinster. I en rapport publicerad i Läkartidningen, skriven av läkare och utvecklingsansvariga i Västerbottens läns landsting och Innovationsplatsen vid Karolinska universitetssjukhuset, uttrycks det så här:

Det finns många vinster med vård på distans, vissa mer tydliga och konkreta än andra som kräver vetenskapliga studier för att påvisa nyttoeffekter. Tydligaste nyttan är färre resor och därmed besparingar i framför allt tid, vilket leder till ekonomiska vinster för både personal, patient och anhöriga. (Läkartidningen 2014-10-22) 
I exemplet beskrivs den digitala vården som någonting som ger "nyttoeffekter" enligt den välkända devisen tid är pengar, där tiden görs till en resurs som ses som värdefull i sig (se Lakoff \& Johnson 1980). Som organiserande ekonomisk metafor blir tid någonting som sjukvården kan tjäna in, spara och vinna, men också sälja och därmed generera vinst. De som använder teknologin (vårdgivare, patienter och anhöriga) kommer att vinna tid, vilket framstår som önskvärt enligt en sådan organiserande diskursiv logik. I andra exempel beskrivs e-hälsa på liknande sätt då befolkningen sägs ha en önskan om att inte behöva förflytta sig från hemmet eller vänta långa tidsperioder för att få vård. Teknologin länkas då till ekonomi eftersom den föreställs fungera som en väg eller en brygga för att minska både avstånden, väntetiden och ojämlikheten i vården som finns i landet. Teknologin blir kort sagt ett verktyg för att hushålla med resurser. I flera av artiklarna nämns även vikten av att teknologin måste vara säker för patienterna eftersom försämrad patientsäkerhet inte är ett pris de är villiga att betala när sätten att bedriva vårdverksamhet förändras.

- Det finns ett behov och en önskan hos befolkningen att få den typen av tjänster.

Det är ju väldigt lätt att förstå; att slippa transportera sig, att slippa vänta - det är ju bekvämt. Det viktiga för oss är att leverera det på ett säkert sätt. Och man vill se om det kan vara ett sätt att minska ojämlikheten mellan stad och glesbygd. (Läkartidningen 2018-02-07)

Men även om berättelser om e-hälsoteknikens möjligheter att generera olika typer av tidsvinster förekommer, så är det främst kostnaderna räknat i rena pengar som det talas om. Betydelsen av e-hälsa konstrueras inte bara som någonting som besparar samhället resurser i termer av att vården ska gå snabbare och bli mer flexibel utan flera artiklar i materialet betonar den ökande monetära belastning som uppstår i kölvattnet av de nya vårdaktörernas etablering. I takt med att de digitala vårdbesöken ökar, sägs kostnaderna för privatägd e-hälsa öka lika fort. I en nyhetsartikel från 2017 med titeln Digital vård får pengarna att rulla skriver Läkartidningen så här:

För patienter från Stockholms läns landsting, som står för 4 procent av besöken hos Kry och Min Doktor, har kostnaderna för landstinget stigit från 67000 kronor per månad för ett år sedan till närmare fem miljoner kronor för mars $i$ år. [...] - När landstingen ser hur fakturorna från nätläkarbolagen ökar finns en risk för att nätläkarnas verksamhet dränerar resurser från de vanliga vårdcentralerna. (Läkartidningen 2017-07-26) 
Metaforen "pengarna rullar" gör att e-hälsans kostnader kan associeras till någonting som är närmast okontrollerbart och svårt att stoppa. I exemplet föreställs den nya teknologin och organiseringen av densamma alltså inte ge upphov till mer resurser för vården utan tvärtom finns risken att den dränerar vården ur ett ekonomiskt perspektiv. De nya digitala vårdföretagen sägs leda bort resurser från ett vårdutrymme till ett annat på ett oönskat sätt. Den här typen av diskussioner om företagens uttag av ersättning från skattemedel är ofta återkommande i materialet och gestaltas som tämligen oroande. Även i Dagens Medicin länkas frågan om arvodeskostnader till ökade kostnader för skattebetalare och därför menar många i debatten att en reglering av företagens uttag är nödvändig. 2017 låg kostnaden för nätläkarbesök mellan 1 200 och 2200 kr per besök. En reglering av företagens ersättningsuttag har emellertid skett därefter i flera etapper. I många av artiklarna nämns Sveriges Kommuner och Landsting (SKL) som viktig för regleringen av e-hälsans "skenande kostnader". Det senare är något som branschen själv målar upp som ett hot mot deras kommersiella verksamhet:

\begin{abstract}
$\mathrm{Nu}$ har SKL:s sjukvårdsdelegation och styrelse fattat beslut om en rekommendation att SKL:s medlemmar ska fakturera 650 kronor för utomlänsbesök i primärvården, vilket är vad de digitala läkarbesöken räknas som. En av de stora aktörerna inom digital vård, Min Doktor, riktar skarp kritik mot förslaget till sänkt ersättning. - Det finns ingen som kan bedriva vård för den ersättningen. (Dagens Medicin 2017-05-17)
\end{abstract}

Som citatet visar, framstår en reglering av företagens uttag som problematisk för att överhuvudtaget kunna bedriva vård. Trots företagens skarpa kritik har avgiftstak införts, men likväl uttrycks en oro för att kostnaderna för samhället ökar. På två år sägs utgifterna i en region ha ökat 54 gånger från 220000 kronor till 11800000 kronor per månad (Läkartidningen 2018-01-24). I Läkartidningens nyhetsartikel Nätläkarnotan har ökat kraftigt (Läkartidningen 2019-01-22) beskrivs också vården i termer av ett slags flöde där patienter "slussas" fram, vilket leder till mer utgifter för samhället.

I materialet framträder sammanfattningsvis bilder av e-hälsa där digital vård blir kopplad till tidsvinster i form av kortade avstånd, ökad flexibilitet samt idén att digital teknologi ska utjämna skillnaderna i tillgång till vård i olika regioner. Den rationalisering som e-hälsa förväntas skapa i termer av kortade avstånd och mer direkt vård kan också tolkas som en sorts samhällelig acceleration. När föreställningar om tid görs till en resurs som kan tjänas in sker samtidigt, menar Rosa, en kommodifiering av själva tidsbegreppet (2013 s. 161). I vårdsektorn blir tiden en vara som köps och säljs av landstingen och de nya digitala entreprenörerna i e-hälsobranschen, och ju fler löften 
om tidsvinster som kan säljas in, desto mer ekonomiska vinster kan genereras, vilket kan sägas följa den ekonomiska logiken att tid är pengar. Samtidigt beskrivs införandet av e-hälsa, och den tidsrationalisering som antas följa därav, som någonting ekonomiskt problematiskt. I materialet uttrycks det på så sätt att kostnaderna för skattebetalarna förefaller öka närmast okontrollerbart i takt med att nätläkarbesöken ökar.

\section{Marknadifiering av e-hälsa som etiskt problem}

Ett annat sätt på vilket e-hälsans betydelser organiseras, som även länkar till ekonomi, handlar om marknadifiering av e-hälsa som ett etiskt problem. Den organiserade metaforen rymmer en tydlig kritik av den politisk-ekonomiska organiseringen av vården där kommersialisering av digital vård problematiseras utifrån etiska spörsmål som är kopplade direkt till läkarprofessionen. I debatten återfinns exempelvis kritik mot att vård drivs av privata företag som sägs göra både patientskap och vårdgivande till handelsvaror som i allt snabbare takt, och i högre utsträckning, ska köpas och säljas av såväl individer som offentliga och privata aktörer. Så här inleds en av debattartiklarna om e-hälsa skriven av fyra läkare med rubriken Total "make over" hotar läkaryrket.

Förr fanns det marknader här och var i samhället. Nu finns det öar av samhälle i den stora marknaden. [...] Det säger något väsentligt om samhällsutvecklingen i stort: I allt större omfattning blir vi alla säljare och köpare på en svårfångad marknad. [...], och e-hälsa förespeglar möjligheten till en hälsa bortom kropp och själ, en hälsa som kan köpas på nätet lika enkelt som prylar, kläder och böcker. (Läkartidningen 2017-10-09)

Citatet illustrerar ett sätt att förstå och begripliggöra e-hälsa där de nya formerna av digitaliserad vård knyts till konsumtion av vård. Den organiserande metaforen är i det här fallet "marknaden", som föreställs utbreda sig som ett hav och där "samhället" beskrivs som avskilda öar i ett stort vatten. I denna övärld föreställs vi alla bli "säljare och köpare", och "hälsa" blir en produkt i mängden att konsumera i det digitaliserade samhället. I samma artikel skriver författarna:

[E-hälsa] har fått dem att hoppas på en ny, skön värld där stora problem kan lösas via tekniken, utan direkt mänsklig kontakt. Man menar att det blir snabbare så, mera tillgängligt och framför allt billigare. Den senare illusionen fick sig en törn när flera stora vårdbolag systematiskt började utnyttja politikers godtrogenhet genom ockerpriser på nätkonsultationer. [...] Hur är det möjligt att så genomgripande organisationsförändringar kunnat sjösättas utan väl upplagda, genomförda och utvärderade pilotstudier? [...] Är evidensbaserad medicin och etiska regler ett spel för gallerier? (Läkartidningen 2017-10-09) 
I exemplet konstrueras en förståelse av e-hälsa där teknologin tycks rationalisera bort det fysiska och tidskrävande mötet mellan patient och läkare. Ju längre tid ett möte tar, desto dyrare föreställs vården bli: "Man menar att det blir snabbare så, mera tillgängligt och framför allt billigare." Ett sådant resonemang kan sägas följa en kritik av en kapitalistisk ekonomisk logik där det investerade kapitalet riskerar att gå förlorad om inte teknologin kan göra att fler vårdmöten produceras i allt snabbare takt (jfr Rosa 2013 s. 163). Debattörerna målar således upp en konflikt mellan å ena sidan marknadstänkande och å andra sidan etiska och vetenskapliga medicinska principer så till den grad att det sägs hota hela läkarprofessionen. Även i andra debattinlägg skrivna av läkare synliggörs konfliktytan mellan å ena sidan politiska visioner om e-hälsa och teknologiska innovationer och å andra sidan den behovsprövade vården.

Vi måste vara uppmärksamma på den motsättning som kan finnas mellan en
politisk dimension/vision om tillgänglighet och innovation för innovationens egen
skull och vikten av att prioritera vårdens knappa resurser. Innovation ska leda till
ökad kvalitet och effektivitet i vården, men får inte tränga undan patienter med
stora behov. [...] Vi ifrågasätter all marknadsföring av "läkarbesök online", som
saknar flera av de viktigaste delarna i ett läkarbesök - det personliga mötet, fysisk
undersökning och möjlighet till provtagning direkt. (Läkartidningen 2016-12-22)

Nya digitala vårdpraktiker tillsammans med reklam för "läkarbesök online" framställs som tomma begrepp ("innovation för innovationens egen skull") och som om de tränger undan vad som framstår som den traditionella vårdens mest centrala del "patienter med stora behov". I citatet blir den fysiska undersökningen där personalen träffar patienten central och föreställs vara det som konstituerar vad det innebär att vara läkare och att driva en vårdcentral. Därigenom blir ifrågasättandet av e-hälsoföretagen begripliggjord som en etisk konflikt. I en nyhetsartikel i Läkartidningen intervjuas läkare som uttrycker en liknande skepsis mot den marknadsdoktrin som tycks ha uppstått i samband med en avreglerad vårdapparat:

Men hon menar att det råder en hajp kring e-hälsa utan att man preciserat vilka problem den egentligen ska lösa. - Handlar det bara om efterfrågan på en vilda västern-marknad där konsultföretag och teknikföretag gräver guld, då slirar man i definitionerna av behov och efterfrågan. (Läkartidningen 2017-09-06)

I exemplet länkas e-hälsa till "en vilda västern-marknad", som gör att teknologin framstår som ett slags resa mot rikedom för företagen. Konsulter och företag inom vården gestaltas som om de fått guldfeber, men vad e-hälsa ska vara bra för i övrigt framstår som mer otydligt: "det råder en hajp kring e-hälsa utan att preci- 
sera vilka problem den egentligen ska lösa". Vidare debatteras frågan om att vårdföretag använder reklam för att nå nya och fler konsumenter av vård och att vård saluförs på samma sätt som andra varor och tjänster. Två företrädare för etik- och ansvarsrådet i Läkartidningen skriver så här i en artikel med titeln Digital vård är inget mobiltelefonabonnemang:

\begin{abstract}
Den som marknadsför läkarverksamhet kan då inte spela på samma register som den som säljer mobilabonnemang eller spabehandlingar. På förekommen anledning finns sedan lång tid etiska regler som läkaren har att rätta sig efter om han eller hon vill vara en del av den professionella gemenskapen. [...] Bakgrunden är att samhället ska kunna lita på att förskrivning inte leder till egen vinning för förskrivaren eller ett felaktigt utnyttjande av offentliga medel. Vi behöver en sjukvård med hög kvalitet och tillgänglighet och med hög etisk medvetenhet. (Läkartidningen 2018-04-11)
\end{abstract}

Begrepp som "mobilabonnemang" och "spabehandlingar" gör att e-hälsa placeras utanför den etablerade diskursen om vad medicinsk vård är och bör vara. Genom musikmetaforen "inte spela på samma register" konstrueras en betydelse av e-hälsa där de föreställs spela på fel sätt. E-hälsobranschens "marknadsföring" lokaliserar företagen vid sidan av "den professionella gemenskapen" eftersom det framstår som osäkert om vården de försöker saluföra är behovsprövad eller om vården som erbjuds grundar sig i "egen vinning för förskrivaren". Marknadsföring av vård signalerar kort sagt bristande "etisk medvetenhet". Flera artiklar tar även upp frågan om jäv som kan uppstå i samarbeten mellan digitala vårdföretag och apotek, ofta med samma huvudägare. Läkarförbundet uttrycker det på följande vis i Läkartidningen:

\footnotetext{
Nuvarande utveckling har också aktualiserat ägar- och samarbetsfrågor mellan vård och apotek. Att nätbolag samarbetar och samverkar med apotek utvecklar jävssituationer som är olyckliga. För patienten blir det svårt att överblicka och se konsekvenserna av ett sådant samarbete. Vi anser att korsägande eller reglerad samverkan mellan vårdgivare, apotek eller läkemedelsindustri bör undvikas. (Läkartidningen 2018-02-07)
}

Digitalt vårdgivande blir i denna del av debatten inte så mycket relaterat till vårdpraktiker som handlar om omsorg av patienten utan snarare till problemen med extern kommunikation i form av aggressiv marknadsföring och till avsaknaden av den läkaretiska principen att all vård ska vara behovsprövad. Hur kan man förstå kritiken från (delar av) läkarkåren och facket? En tolkning är att teknologins införande tillsammans med den avreglerade vårdsektorn hotar deras yrkesidentitet eftersom 
kommersialism och vård utgör två oförenliga poler. Kritiken mot vårdens förändring kan även tolkas som att debattörerna ger uttryck för en tillbakablickande syn på vårdpraktiker där mötet mellan patient och vårdpersonal går långsammare eftersom medicinsk personal har tid till personliga kvalitativa möten med patienter. På det sättet sker även en politisering av e-hälsovården. Dikotomierna snabb/långsam, virtuell/fysisk, kommersialism/behovsprövning utgör således skärningspunkter genom vilka e-hälsa tillskrivs mening.

\section{Slutsatser}

Syftet med den här artikeln var att undersöka hur e-hälsa som begrepp tillskrivs mening i svensk medicinsk fackpress samt analysera de konfliktlinjer som präglar denna betydelsebildning i en tid då svensk sjukvård genomgår en stor förändring. De frågor som ställdes handlar om hur betydelser av e-hälsa och dess vårdpraktiker skapas i svensk medicinsk fackpress och hur personal, patienter och andra aktörer positioneras i dessa berättelser. Särskilt fokus låg på att identifiera organiserade metaforer (Hansen \& Sørensen 2005) som synliggör de konfliktytor som förekommer i materialet där problem och möjligheter på olika sätt knyts till e-hälsa som ny vårdpraktik. Även om de konkreta effekterna av teknologin och de materiella och praktiska aspekterna av digitala vårdpraktiker inte varit i fokus i den här studien, har målet varit att resonera kring hur artikulationer i debatten kan tänkas påverka aktörer och subjekt som involveras i talet om e-hälsa (patienter, vårdpersonal, företag, samhälle etc.).

Framväxten av e-hälsa kan förstås i termer av en teknologisk acceleration där målet i sig tycks vara teknikutveckling, att komma längre, att införa nya mer effektiva digitala tekniker, vilket kan ses som både en legitimering och en avpolitisering av teknologin. Det är tydligt i avsnittet $e$-hälsa som tävling. I framställningen av e-hälsa är det påtagligt att teknologin, det sociala och det ekonomiska är tätt sammanlänkat. Teknikens materialitet och dess funktioner utgör, som Rosa skriver, själva villkoren för möjligheterna till utökad social acceleration inom en mångfald av områden (Rosa 2013 s. 106). Samtidigt är teknologin inte neutral utan laddas ofta med motsatsfulla betydelser. Som debatten om e-hälsa har visat, handlar det om drömmar om teknologins avtryck på diverse sociala aspekter inom vården som mångsidig tillgänglighet, säkrare kommunikationskanaler mellan patienter och vårdgivare och en vilja att främja jämlik hälsa med hög delaktighet. Det är också tydligt att kraven på att införa nya teknologiska innovationer föreställs drivas av den "ekonomiska motor" vars funktion är att öka tillväxt och effektivitet (Rosa 2013 s. 23). Ekonomi har i materialet utgjort en möjlighet i form av bland annat föreställningar om tidsvinster för vården, men samtidigt har e-hälsans ekonomi artikulerats på motsatt sätt som ett stort problem i termer av ökade kostnader för samhället. 
Kritiken om e-hälsa, främst från representanter för läkarkåren, har handlat om att digitala lösningar tenderar att göra patienterna till konsumenter, och att en sådan positionering riskerar att förändra professionens yrkesidentitet. Marknadstänkande och läkaretik går enligt många debattörer inte ihop och att patienter görs om till konsumenter sägs leda till etiska problem. Tidigare forskning visar att idén om att patienter betraktas som konsumenter är relativt ny. Begreppet patient kommer från det latinska ordet pati som betyder "att lida". Konsument kommer från consumere och betyder "att använda". Om detta skriver Goldstein och Bowers i en amerikansk studie som visar att konsument började användas som synonym till patient i medicinska sammanhang första gången under 1930-talet i USA och att det under 1980talet blev allt vanligare när det amerikanska samhället blev mer marknadsanpassat (Goldstein \& Bowers 2015 s. 162). De noterar också en betydelseglidning eftersom ordet konsument pekar på en högre aktivitetsgrad än det mer passivt konnoterande ordet patient. Att patienter ses som konsumenter syns även i litteraturen om e-hälsa. Melander Wikman uttrycker det så här: "Patienten ses som en konsument med tillgång till information från Internet som gör att hon eller han kan ställa större krav på sitt omhändertagande och är också mer informerad om sin sjukdom” (Melander Wikman 2012 s. 19).

När vissa av debattörerna talar om att vårdföretag inte ska sälja vård likt andra varor på en marknad, kan man se det som ett uttryck för en kritik mot konsumtionssamhället (Bauman 2008) och mot det nyliberala systemskifte som andra forskare menar kommit att karaktärisera svensk vårdpolicy (Andersson \& Kvist 2015; Lindberg \& Lundgren 2018; Dahlgren 2018). Den typ av avreglering av offentlig sektor som gestaltas i materialet som här undersökts, där "konsultföretag och teknikföretag gräver guld", är ofta mycket ingående, menar Bauman, samtidigt som den privata sektorn får fortsatt statligt stöd. Dessa privatiseringsprocesser är, enligt honom, en förutsättning för framväxten av ett konsumtionssamhälle där grundläggande behov (som exempelvis vård och omsorg) omvandlas till varor och tjänster som bjuds ut till försäljning för att konsumeras på en marknad.

Kritiken mot marknadifiering av e-hälsovård blir på det sättet en politisering av e-hälsa och kan även ses i ljuset av "det fria vårdvalet" som infördes på politisk nivå i Sverige när lagen om valfrihetssystem (LOV) instiftades 2009 (2008:962). Den förändringen innebar att välfärden konkurrensutsattes och att medborgarna skulle börja välja vårdgivare på en marknad (Lindberg \& Lundgren 2018). Det innebar samtidigt att vårdaktörerna skulle konkurrera om patienter och att det skapades en ny apparat av administration och politisk kontroll från statens sida. LOV kan i den meningen ses som ett ideologiskt uttryck för det Bauman kallar för "homo eligens", eller "den väljande människan" (Bauman 2008 s. 51), vars valfrihet ofta beskrivs som ett uttryck för individens autonomi men inte sällan kan ha drag av både tvång och ofrivillighet i de 
valsituationer människor ställs inför i vardagen. Hur påverkar framväxten av e-hälsa vad det innebär att vara vårdtagare och vårdgivare? Som både Campell (1990) och Lindberg och Lundgren (2018) påpekar är patienter ofta sårbara och har inte alltid möjlighet eller ens lust att välja vårdvägar. Om vården behandlar patienter som konsumenter och vårdgivare tillskrivs rollen som försäljare, vad händer med omsorgen? Det material som här har studerats visar hur den politisk-ekonomiska förändring som e-hälsa kan sägas vara en del av tycks skapa en förskjutning i diskursen om svensk vård. Detta område är någonting som bör studeras vidare när det gäller patienters och medicinsk personals konkreta erfarenheter av e-hälsobaserad sjukvård.

\section{Referenser}

Andersson, K. \& Kvist, E. (2015) The neoliberal turn and the marketization of care. The transformation of eldercare in Sweden. European Journal of Women's Studies, 22(3): 274-287.

Andersson, O., Sjögreen, J. \& Åsberg, H. (2017) Nätläkarbolagen dränerar en underfinansierad primärvård. Dagens Nyheter (2017-03-02).

Bauman, Z. (2008) Konsumtionsliv. Göteborg: Daidalos.

Bengtsson, L. (2019) KRY förvärvar psykologiappen Enjo. https://www.kry.se/press/nyheter/ kry-forvvrvar-psykologiappen-Enjo/

Campell, A. (1990) The patient as consumer. British Journal of General Practice 1990;

40, 131-133.

Dagens Medicin, 2014-04-09, Bidra till årets landskamp i vård-IT

Dagens Medicin, 2015-04-15, En dag för den moderna biotekniken

Dagens Medicin, 2016-04-13, Vitalis - en fantastisk och motsägelsefull mässa

Dagens Medicin, 2016-06-22, "Helt feltänkt med en statlig vision för e-hälsa"

Dagens Medicin, 2017-05-17, Ersättning för digital vård halveras

Dagens Medicin, 2017-11-08, Alla måste fråga sig: Kan detta göras bättre med modern

teknik?

Dahlgren, G. (2008) Neoliberal reforms in Swedish primary health care. For whom and for what purpose? International Journal of Health Services, 38(4), 697-715.

Dahlgren, G. (2018) När sjukvården blev en marknad - effekter och alternativ. Premiss förlag.

Ekeland, A.G., Bowes, A. \& Flottorp, S. (2010) Effectiveness of telemedicine. A systematic review of reviews. International Journal of Medical Informatics, 79(11): 736-771.

Forslund, L. \& Röstin, S. (2017) Digitala läkarbesök kan spara 180 miljarder. Dagens Nyheter (2017-03-06).

Goldstein, M. \& Bowers, D. (2015) The patient as consumer. Empowerment or commodification? Currents in contemporary bioethics. The Journal of Law, Medicine \& Ethics, 43(1): 162-5.

Hansen, A. \& Sørensen, E. (2005) Polity as politics. Studying the shaping and effects of discursive polities. I: D. Howarth \& J. Torfin (red.) Discourse theory in European politics. Identity, policy and governance. Palgrave Macmillan.

Heijbel, L. \& Tullberg, M. (2019) Doktorse och AniCura utvecklar vårdapp för husdjur. [https://www.anicuragroup.com/sv/press-och-media/pressmeddelanden/2019/doktor. se-och-anicura-utvecklar-vardapp-for-husdjur/]. 
Kangero, H. \& Persson, D. (2017) Digitaliseringen kan spara miljarder. Dagen Nyheter (2017-03-03).

Karlsson, J. (2018) Krys vd om nya miljardvärderingen: "Expansionen kommer att kosta". Dagens Industri (2018-06-12).

Kruse, C., Karem, P., Shifflett, K., Vegi, L., Ravi, K. \& Brooks, M. (2018). Evaluating barriers to adopting telemedicine worldwide. A systematic review. Journal of Telemedicine and Telecare, 24(1):4-12.

Laclau, E. \& Mouffe, C. (1985). Hegemony and socialist strategy. London:Verso.

Lag (2008:962) om valfrihetssystem [https:/www.riksdagen.se/sv/dokument-lagar/dokument/ svensk-forfattningssamling/lag-2008962-om-valfrihetssystem_sfs-2008-962].

Lakoff, G. \& Johnson, M. (1980) Metaphors we live by. Chicago: University of Chicago Press.

Leijonhufvud, J. (2017) Halv miljard till digital vård 2016. Dagens Industri (2017-01-18).

Leijonhufvud, J. (2020) Nätläkaren Kry coronarusar: "Vi har nästan dubblat vår volym". Dagens Industri (2020-04-23).

Lindberg, J. \& Carlsson, E. (2018) Digitala vårdlandskap. Kritiska reflektioner om e-hälsa i glesbygden. Socialmedicinsk tidskrift, 95(1).

Lindberg, J. \& Lundgren, A.S. (2018) Positioning the ageing subject. Articulations of choice in Swedish and UK health and social care. Policy Studies. [https://doi.org/10.1080/01442872.20 19.1599839].

Lupton, D. (2014) Critical perspectives on digital health technologies. Sociology Compass 8(12):1344-1359.

Lupton, D. (2017) Self-tracking, health and medicine. Health Sociology Review, 26(1): 1-5.

Lupton, D. (2018) Digital health. Critical and cross-disciplinary perspectives. London: Routledge.

Läkartidningen, 2011-08-10, Konsulten bleknade av min hög med elektronik.

Läkartidningen, 2014-10-22, Telemedicin leder till ökad patientnytta.

Läkartidningen, 2016-03-26, Världsbäst på e-hälsa kräver delaktighet.

Läkartidningen, 2016-12-22, Vitsen med virtuell vård. Regler för marknadsföring av läkarverksamhet behöver uppdateras.

Läkartidningen, 2017-05-03, "Fokusera inte bara på teknik".

Läkartidningen, 2017-07-26, Digital vård får pengarna att rulla.

Läkartidningen, 2017-09-26, Läkare i intensiv debatt om e-hälsans betydelse.

Läkartidningen, 2017-10-09, Total "make-over" hotar läkaryrket. Om marknad, samhälle,

etik och medicinsk vetenskap.

Läkartidningen, 2018-01-24, Så mycket kostar digital vård.

Läkartidningen, 2018-02-07, Landstingen tar upp kampen om digital vård.

Läkartidningen, 2018-02-07, Jämlik vård efter behov behövs också på nätet.

Läkartidningen, 2018-03-14, Digitalisering är ett medel, inte ett mål.

Läkartidningen, 2018-04-11, Digital vård är inget mobilabonnemang.

Läkartidningen, 2019-01-22, Nätläkarnotan har ökat kraftigt.

Melander Wikman, A. (2012) Definitioner och modeller för e-hälsa. I: G. Gard \& A. Wikman Melander (red.) E-hälsa. Innovationer, metoder, interventioner och perspektiv. Lund: Studentlitteratur.

Melander Wikman, A., Jansson, M. \& Bergvall-Kåreborn, B. (2012) Från MobiHealth till MyHealth@Age. Utveckling av teknik med deltagande metodik. I: G. Gard \& A. Wikman Melander (red.) E-hälsa. Innovationer, metoder, interventioner och perspektiv. Lund: Studentlitteratur.

Rosa, H. (2013) Social acceleration. A theory of modernity. New York: Colombia University Press. 


\section{Socialvetenskaplig tidskrift 2020:2}

Sharon, T. (2016) Self-tracking for health and the quantified self. Re-articulating autonomy, solidarity, and authenticity in an age of personalized healthcare. Philosophy and Technology, 30(1): 93-121.

Ström, V. (2017) Nu är KRY ett miljardbolag. Dagens Industri (2017-06-29).

SVT (2020) [www.svt.se/nyheter/inrikes/rekordkostnader-for-privata-vardappar-under-corona-pandemin].

Torfing, J. (2005) Discourse theory. Achievements, arguments, and challenges. I: D. Howarth \& J. Torfing (red.) Discourse theory in European politics. Identity, policy and governance. New York: Palgrave Macmillan.

Törnwall, M. (2018) Kontroversiell nätläkare vill starta fler vårdcentraler. Svenska Dagbladet [https://www.svd.se/kontroversiell-natlakare-vill-starta-fler-vardcentraler].

Wisterberg, E. (2016) Sparkade vd:n - nu tar Min Doktor in ytterligare 45 miljoner [https://www. breakit.se/artikel/5893/sparkade-vd-n-nu-tar-min-doktor-in-ytterligare-45-miljoner].

Žižek, S. (1989) The sublime object of ideology. London: Verso. 